\title{
Modeling the additive stand biomass of Larix spp. for Eurasia
}

\author{
Vladimir Andreevich Usoltsev ${ }^{1,2}$, Seyed Omid Reza Shobairi ${ }^{2 *}$, Viktor Petrovich Chasovskikh ${ }^{2}$ \\ ${ }^{1}$ Botanical Garden, Russian Academy of Sciences, Ural Branch, 8 Marta 202a St, Yekaterinburg, \\ 620144 Russian Federation \\ ${ }^{2}$ Ural State Forest Engineering University, Sibirskii Trakt 37 St, Yekaterinburg, \\ 620100 Russian Federation, \\ *e-mail: Omidshobeyri214@gmail.com
}

Received: 6 November 2018 / Accepted: 30 January 2019

\begin{abstract}
When using the unique in terms of the volumes of database on the level of a stand of the genus Larix Mill., the transEurasian additive allometric models of biomass for Eurasian larch forests are developed for the first time, and thereby the combined problem of model additivity and generality is solved. The additive model of forest biomass of Larix is harmonized in two levels, one of which provides the principle of additivity of biomass components, and the second one is associated with the introduction of dummy independent variables localizing model for eco-regions of Eurasia. Comparative analysis of the biomass structure of larch stands of different ecoregions at the age of 100 years shows, that the greatest values of biomass (210-450 t/ha) correspond to the regions adjacent to the Atlantic and Pacific coasts, as well as to the regions, located at the southern limit of larch growing area and the lowest - to northern taiga regions of Siberia, where larch grows on permafrost. The biomass indices of different ecoregions differed not only in absolute value but also in biomass ratios of different components; for example, the proportion of needles in the aboveground biomass is maximum (5.0-7.3\%) in the northern taiga of Central Siberia and the Far East on permafrost and is minimum (1.4-1.9\%) in larch forests of upper productivity having biomass values 210-450 t/ha. The proposed model and corresponding tables for estimating stand biomass makes them possible to calculate larch stand biomass on Eurasian forests when using measuring taxation.
\end{abstract}

Keywords: allometric models, biological productivity, biomass of forests; Larix Mill., sample plots.

\section{Introduction}

Evaluation of biological productivity and carbon-depositing ability of forests is currently one of the priority directions of forest ecology in relation to global climate change. In recent years, scientific direction associated with the evaluation of the biological productivity of trees and stands, is the most intensely developed in at least two aspects: (1) in compiling the world's data bases on actual biological productivity at the levels of forest stands and single-trees with development of their global and transcontinental pat-

${ }^{*}$ corresponding author. terns (Gill \& Jackson, 2000; Usoltsev et al., 2002; Schenk \& Jackson 2002, 2003; Crowther et al., 2015; Poorter et al., 2015; Liang et al., 2016; Jucker et al., 2017) and (2) in the development of methodological backgrounds of regression modeling with the aim to improve the accuracy of our estimates and the correctness of the empirical models of biological productivity of forests and their constituent trees (Parresol, 2001; Usoltsev et al., 2002; Dong et al., 2015a, b).

Generic allometric models were intensively developed only on aboveground biomass, they seemed promising for estimating forest biomass in total, usually within the single wood species (Tritton \& Hornbeck, 1981; Schmitt \& Grigal, 1981; Crow, 1983; Pastor et al., 1984; Grigal 
\& Kernik, 1984; Zianis \& Mencuccini, 2003; Case \& Hall 2008; De-Miguel et al., 2014), and in tropical forests also within the totality of different species (pantropical models) (Ogawa et al., 1965; Crow, 1978; Chave et al., 2005, 2014; Vieilledent et al., 2012; Rutishauser et al., 2013; Stas et al., 2017).

But because various biomass components are characterized by different rates as growth and mortality, they make a different contribution to the cycling of substances and should be evaluated separately. Therefore, the development of generic allometric models is replaced by a phasing out of them and moving on to the concept of their harmonizing. To the latter at least two directions can be attributed: (1) construction of compatible regional models based on dummy variables (Usoltsev et al., 2002; Dieguez-Aranda et al., 2006; Nord-Larsen, 2006; Li et al., 2006; Wang et al., 2007, 2008; Fehrmann et al., 2008; Lang, 2008; Tang et al., 2008; Li \& Zhang, 2010; Zeng et al., 2011; Fu et al., 2012, 2013, 2017; Zeng, 2015) and (2) the development of compatible models based on principles of additivity of biomass component composition (Parresol, 2001; Carvalho \& Parresol, 2003; Bi et al., 2004, 2015; Sanquetta et al., 2015; Dong et al., 2015a, b; Dong et al., 2016). Additive allometric models are designed today exclusively at the level of single trees. Similar models developed at the level of forest stands, to which is dedicated this work, are presented today with single researches, that are fulfilled, for example, in Pinus radiata (D. Don) plantations (Bi et al., 2010) and in mixed spruce-fir forests of Eurasia (Usoltsev et al., 2017a, b), and models were built using alternative algorithms of harmonization that are defined respectively as «from private-to-general" (Bi et al., 2010) and «from general-to- private (Usoltsev et al., 2017a, b) without attempting any of their regionalization.

Thus, the modern methods of modelling the biological productivity of trees and tree stands have been developed towards additivity of biomass components ( $\mathrm{Bi}$ et al., 2010; Dong et al., 2015b) and towards transition from «pseudo-generic» allometric models to really genericl, involving regionalization of biomass models by introducing dummy variables (Fu et al., 2012), that usually fulfilled on local sets of actual biomass of trees and tree stands. We generated the database of forest stand biomass for the main forest species in Eurasia (Usoltsev, 2010, 2013), that has enabled these modern methodologies to be implemented on the entirely different, higher level, namely to begin modelling additive biomass on transcontinental level.

So far, the additivity principle is implemented only for local models of forest stand biomass (Bi et al., 2010). Its complexity and structural unwieldiness of analytical expression, apparently, are the reason that nowadays it is not implemented at the continental level, for example, by the dismemberment of a general additive biomass model on a set of compatible regional sub-models, marked by dummy variables or in some other way. Previously (Usoltsev et al., 2017a, b) the transcontinental additive biomass models of forest stands of Norway spruce ( $P i$ cea Dietr.) and fir (Abies Mill.) growing on the territory of Eurasia were first proposed, that are generic additive models for these species i.e. without taking into account their regional specificities.

In this article, the first attempt to develop transcontinental harmonized allometric models of larch (genus Larix Mill.) forest stand biomass, which combine both mentioned by Jacobs and Cunia (1980) approaches, namely, ensuring the principle of additivity of biomass component composition and localizating (dismemberment) of biomass additive model on regions of Eurasia by introducing dummy variables. In other words, an attempt is made to solve the problems of combining additivity and totality of models. These models will provide the basis for the development of trans-continental regional standards for evaluation biomass of trees and forest stands.

\section{Material and methods}

Of the database mentioned the material in a number of 384 sample plots with estimations of larch forest stand biomass ( $\mathrm{t} / \mathrm{ha})$ is extracted. Genus Larix Mill. is introduced by eight species (correspondingly L. decidua Mill., L. sukaczewii N.Dyl., L. sibirica L., L. gmelinii Rupr., L. cajanderi Mayr., L. olgensis A.Henry, L. principis-rupprechtii Mayr, L. leptolepis Gord.; taxonomy according to Sokolov et al., 1977, and Bobrov, 1978), distributed across twelve eco-regions and designated respectively with the twelve dummy variables from $X_{0}$ to $X_{11}$ (Table 1). The distribution of sample plots, on which the larch forest biomass is measured in ecoregions of Eurasia, is shown in Figure 1.

According to the structure of disaggregation three-step model (Tang et al., 2000; Dong et al., 2015b), biomass value, estimated by the total biomass equation, exploded into components according to the scheme presented in Figure 2. The coefficients of the regression models for all three steps are evaluated simultaneously, which ensures additivity of biomass of all the components - total, intermediate and initial (Dong et al., 2015b). 
Table 1. The encoding scheme of the regional actual biomass data sets of 384 larch forest stands of larch

\begin{tabular}{|c|c|c|c|c|c|c|c|c|c|c|c|c|c|c|c|c|c|}
\hline \multirow{3}{*}{$\begin{array}{c}\text { Re- } \\
\text { gion* }\end{array}$} & \multirow{3}{*}{$\begin{array}{c}\text { Species } \\
\text { Larix Mill. }\end{array}$} & \multirow{2}{*}{\multicolumn{11}{|c|}{ Block of dummy variables }} & \multicolumn{4}{|c|}{ Ranges of: } & \multirow{3}{*}{$\begin{array}{c}\text { Plot } \\
\text { quantity }\end{array}$} \\
\hline & & & & & & & & & & & & & & tree number, & mean & & \\
\hline & & \multicolumn{11}{|c|}{$X_{1} X_{2} X_{3} X_{4} X_{5} X_{6} X_{7} X_{8} X_{9} X_{10} X_{11}$} & & per ha & & & \\
\hline WME & L. decidua Mill. & 0 & 0 & 0 & 0 & 0 & 0 & 0 & 0 & 0 & 0 & 0 & $13 \div 210$ & $0.19 \div 2.68$ & $10.2 \div 72.9$ & $4.2 \div 34.0$ & 13 \\
\hline ER & L. sukaczewii N.Dyl. & 1 & 0 & 0 & 0 & 0 & 0 & 0 & 0 & 0 & 0 & 0 & $10 \div 240$ & $0.27 \div 122.5$ & $1.9 \div 51.6$ & $3.6 \div 40.0$ & 58 \\
\hline Tst & L. sukaczewii N.Dyl. & 0 & 1 & 0 & 0 & 0 & 0 & 0 & 0 & 0 & 0 & 0 & $12 \div 55$ & $0.81 \div 6.27$ & $5.2 \div 22.0$ & $4.8 \div 21.1$ & 13 \\
\hline WSn & L. sibirica $\mathrm{L}$. & 0 & 0 & 1 & 0 & 0 & 0 & 0 & 0 & 0 & 0 & 0 & $25 \div 350$ & $0.46 \div 10.7$ & $3.5 \div 32.0$ & $2.8 \div 31.5$ & 19 \\
\hline MSn & L. gmelinii Rupr. & 0 & 0 & 0 & 1 & 0 & 0 & 0 & 0 & 0 & 0 & 0 & $30 \div 380$ & $0.12 \div 5.70$ & $3.2 \div 36.0$ & $2.5 \div 34.0$ & 50 \\
\hline MSs & L. sibirica $\mathrm{L}$. & 0 & 0 & 0 & 0 & 1 & 0 & 0 & 0 & 0 & 0 & 0 & $10 \div 200$ & $0.36 \div 7.19$ & $6.0 \div 30.0$ & $8.9 \div 24.0$ & 17 \\
\hline TB & L. gmelinii Rupr. & 0 & 0 & 0 & 0 & 0 & 1 & 0 & 0 & 0 & 0 & 0 & $40 \div 190$ & $0.11 \div 4.73$ & $4.0 \div 28.4$ & $4.0 \div 25.0$ & 41 \\
\hline ESn & L. cajanderi Mayr. & 0 & 0 & 0 & 0 & 0 & 0 & 1 & 0 & 0 & 0 & 0 & $22 \div 380$ & $0.24 \div 50.8$ & $3.0 \div 29.0$ & $5.4 \div 24.0$ & 53 \\
\hline FEn & L. cajanderi Mayr. & 0 & 0 & 0 & 0 & 0 & 0 & 0 & 1 & 0 & 0 & 0 & $15 \div 250$ & $0.20 \div 52.2$ & $1.1 \div 54.0$ & $4.0 \div 26.0$ & 30 \\
\hline FEs & L. olgensis A.Henry & 0 & 0 & 0 & 0 & 0 & 0 & 0 & 0 & 1 & 0 & 0 & $30 \div 160$ & $0.37 \div 12.6$ & $9.7 \div 29.4$ & $12.0 \div 28.2$ & 12 \\
\hline $\mathrm{Ch}$ & $\begin{array}{l}\text { L. gmelinii Rupr. } \\
\text { L. principis-rupprechtii }\end{array}$ & 0 & 0 & 0 & 0 & 0 & 0 & 0 & 0 & 0 & 1 & 0 & $21 \div 186$ & $0.21 \div 9.30$ & $4.7 \div 37.6$ & $5.9 \div 30.0$ & 33 \\
\hline Jap & L. leptolepis Gord. & 0 & 0 & 0 & 0 & 0 & 0 & 0 & 0 & 0 & 0 & 1 & $9 \div 53$ & $0.37 \div 6.74$ & $6.2 \div 28.6$ & $5.4 \div 23.6$ & 45 \\
\hline
\end{tabular}

${ }^{*}$ Region designations: WME - West and Middle Europe; ER - European part of Russia, central territory; Tst - Turgay steppe; WSn Western Siberia, northern taiga; MSn - Middle Siberia, northern taiga; MSs - Middle Siberia, southern territory; TB - Trans-Baikal lake; ESn - Eastern Siberia, northern taiga; FEn - Far East, northern taiga; FEs - Far East, Primorie; Ch - Northeast China; Jap Japanese islands.

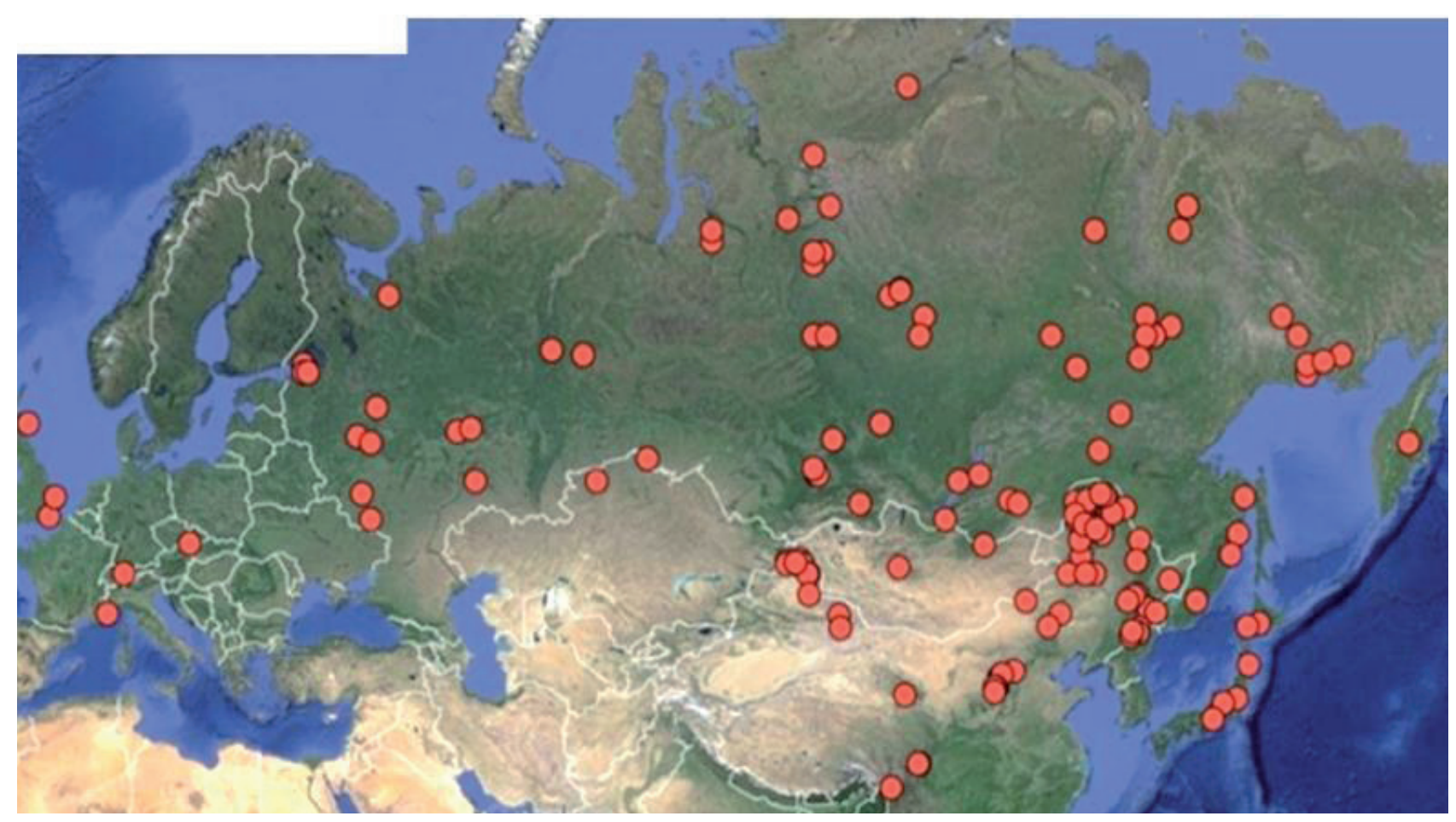

Figure 1. Allocation of sample plots with measured biomass ( $\mathrm{t} / \mathrm{ha}$ ) of 384 stands of larch (genus Larix Mill.) on the territory of Eurasia 


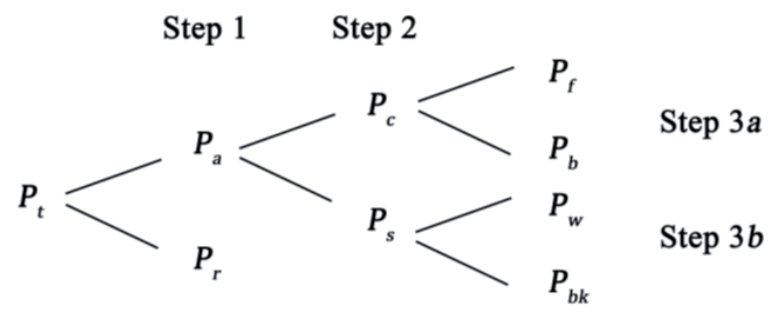

Figure 2. The pattern of disaggregating three-step proportional weighting additive model. Designation: $P_{t^{\prime}} P_{r^{\prime}} P_{a^{\prime}} P_{c^{\prime}} P_{s^{\prime}}, P_{f}, P_{b^{\prime}}, P_{w}$ and $P_{b k}$ are stand biomass respectively: total, underground (roots), aboveground, crown (needles and branches), stems above bark (wood and bark), needles, branches, stem wood and stem bark correspondingly, t per ha

\section{Results and discussion}

The initial allometric models are calculated;

$$
\begin{aligned}
\ln P_{i}=a_{i}+b_{i}(\ln A)+ & c_{i}(\ln A)^{2}+d_{i}(\ln H)+e_{i}(\ln D)+f_{i}(\ln N)+ \\
& +\sum g_{i j} X_{j}
\end{aligned}
$$

where $P_{i}$ - biomass of $i$-th component, t per ha; $A$ - stand age, years; $H$ - mean stand height, $\mathrm{m} ; D$ - mean tree diameter, cm; $N$ - tree number, 1000/ha; $a-g$ - regression coefficients; $i$ - index of biomass component: total $(t)$, aboveground $(a)$, roots $(r)$, crowns $(c)$, stems above bark $(s)$, needles $(f)$, branches $(b)$, stem wood $(w)$ and stem bark $(b k) ; j$ - index (code) in the block of dummy variables coding the ecoregions, from 0 to 11 (see Table 1).

Model (1) after anti-log transformation is given to the form

$$
P_{i}=a_{i} A^{b i} A^{c i(\ln A)} H^{d i} D^{e i} N^{f i} e^{\Sigma g i j X j}
$$

Characteristic of equations (1) obtained by its approximation using actual biomass data, after the introduction of correction to the logarithmic transformation after Baskerville (1972) and the subsequent anti-log transformation to (2) are given in the Table 2. All the regression coefficients of the equations (2) with numerical variables are significant at the level of probability of 0.95 or higher, and the equations are adequate to actual data.

The equations (2) are modified according to the algorithm proposed by Chinese researchers (Dong et al., 2015b) (Table 3), and the final transcontinental additive model of larch biomass component composition on the level of forest stand is given in the Table 4 . The model is valid in the range of actual data of stand age, mean tree height, mean stem diameter and tree density, listed in the Table 1, and is characterized by a double harmonization: one of which provides the principle of biomass component additivity, and the second one relates to the introduction of dummy variables, localizing the model according to ecoregions of Eurasia.

At the next stage of the study a comparison of the adequacy of additive model (see Table 4) and independent equations shown in the Table 2. For their correct comparing the sample plots with incomplete biomass component structure are deleted from the initial harvest data, i.e. only those records are left in which the data are available on both aboveground and underground biomass. The equations (2) are approximated according to such "methodized" data, and their final forms are given in the Table 5. As the "methodized" additive model, and "methodized" independent equations, are tabulated according to actual mass-forming indices of the modified data and the obtained values are compared with harvest biomass data using the formula:

$$
\mathbf{R}^{2}=1-\frac{\sum_{\mathrm{i}=1}^{\mathrm{N}}\left(\mathrm{Y}_{\mathrm{i}}-\overline{\mathrm{Y}}_{\mathrm{i}}\right)^{2}}{\sum_{\mathrm{i}=\mathbf{1}}^{\mathrm{N}}\left(\mathrm{Y}_{\mathrm{i}}-\overline{\mathbf{Y}}_{\mathrm{i}}\right)^{2}},
$$

where $Y_{i}$ is observed value; $\hat{Y}_{i}$ is predicted value; $\bar{Y}$ is the mean of $N$ observed values for the same component.

The results of comparison of the adequacy of two modeling methods are summarized in the Table 6 and they indicate that the adequacy of the two systems of equations for aboveground biomass, underground one and stem biomass are similar and the indices of additive equations for mass of crown, needles and branches are slightly worse. This corresponds to the view (Cunia \& Briggs, 1984; Reed $\&$ Green, 1985), that the correction of internal inconsistency of biomass equations by ensuring their additivity does not necessarily means improvements in the accuracy of biomass estimating. 
Table 2. Characteristic of initial allometric equations for larch stands

\begin{tabular}{|c|c|c|}
\hline 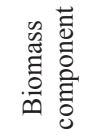 & Independent variables and the regression model coefficients & $\operatorname{adj} R^{2}$ \\
\hline
\end{tabular}

Step 1

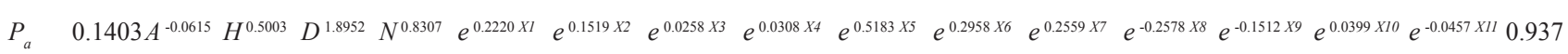

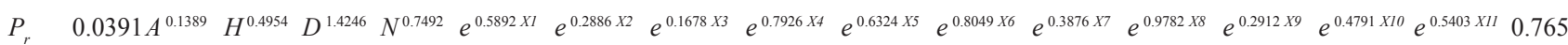

Step2

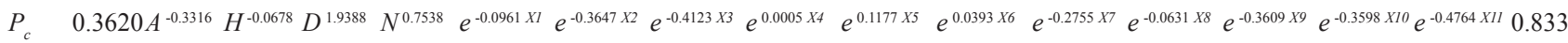

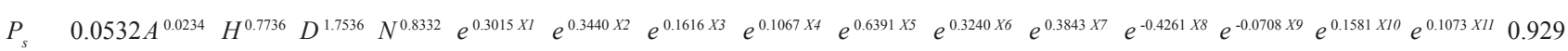

Step $3 a$

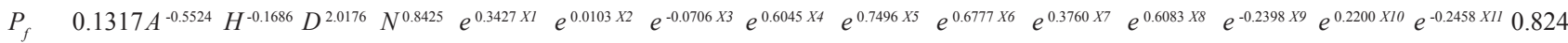

$P_{b} \quad 0.2323 A^{-0.2655} H^{-0.0383} D^{1.9205} N^{0.7200} e^{-0.2118 X 1} e^{-0.4288 X 2} e^{-0.4760 X 3} e^{-0.1666 X 4} e^{-0.0145 X 5} e^{-0.1403 X 6} e^{-0.4521 X 7} e^{-0.2590 X 8} e^{-0.3827 X 9} e^{-0.5037 X 10} e^{-0.5138 X 11} 0.804$

Step $3 b$

$\mathrm{P}_{\mathrm{w}} \quad 0.0432 A^{-0.0843} H^{1.0759} D^{1.5216} N^{0.7924} e^{0.7106 X 1} e^{0.6344 X 2} e^{0.4098 X 3} e^{0.4705 X 4} e^{0.9685 X 5} e^{0.9157 X 6} e^{0.6740 X 7} e^{0.0655 X 8} e^{-0.0387 X 9} e^{0.5357 X 10} e^{0.3935 X I 1} 0.913$

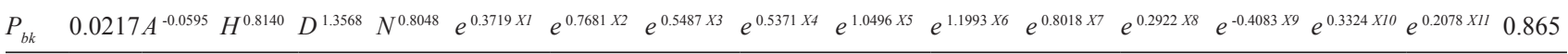

Table 3. The structure of three-step additive model built by proportional weighting (Dong et al., 2015b). Symbols here and further see Figure 2 and equation (1)

\begin{tabular}{|c|c|c|}
\hline Step 1 & $P_{a}=\frac{1}{1+\frac{a_{r} D^{b_{r}} H^{c_{r}}}{a_{a} D^{b_{s}} H^{c_{a}}}} \times P_{\mathrm{t}}$ & $P_{r}=\frac{1}{1+\frac{a_{r} D^{b_{r}} H^{c_{r}}}{a_{a} D^{b_{s} H^{c_{a}}}}} \times P_{\mathrm{t}}$ \\
\hline Step 2 & 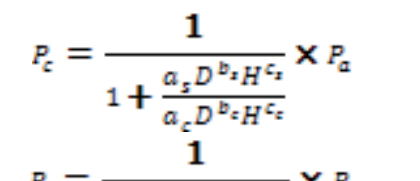 & 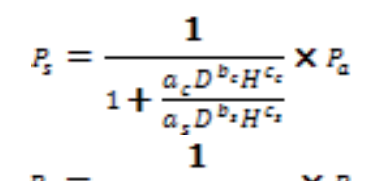 \\
\hline Step $3 a$ & $\begin{array}{c}P_{f}=\overline{1+\frac{a_{b} D^{b_{b}} H^{c_{b}}}{a_{f} D^{b_{f}} H^{c_{f}}}} \times P_{c} \\
\mathbf{1}\end{array}$ & $\begin{array}{c}P_{b}=\frac{}{1+\frac{a_{f} D^{b_{f}} H^{c_{f}}}{a_{b} D^{b_{b}} H^{c_{b}}}} \times P_{c} \\
\mathbf{1}\end{array}$ \\
\hline Step $3 b$ & 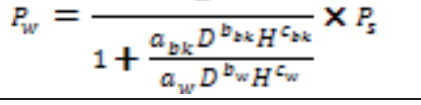 & $P_{b k}=\frac{}{1+\frac{a_{w} D^{b_{w}} H^{c_{w}}}{a_{b K} D^{b_{b k}} H^{c_{b k}}}} \times P_{s}$ \\
\hline
\end{tabular}


Table 4. Three-step additive model of biomass component composition for larch forest stands, built by proportional weighing

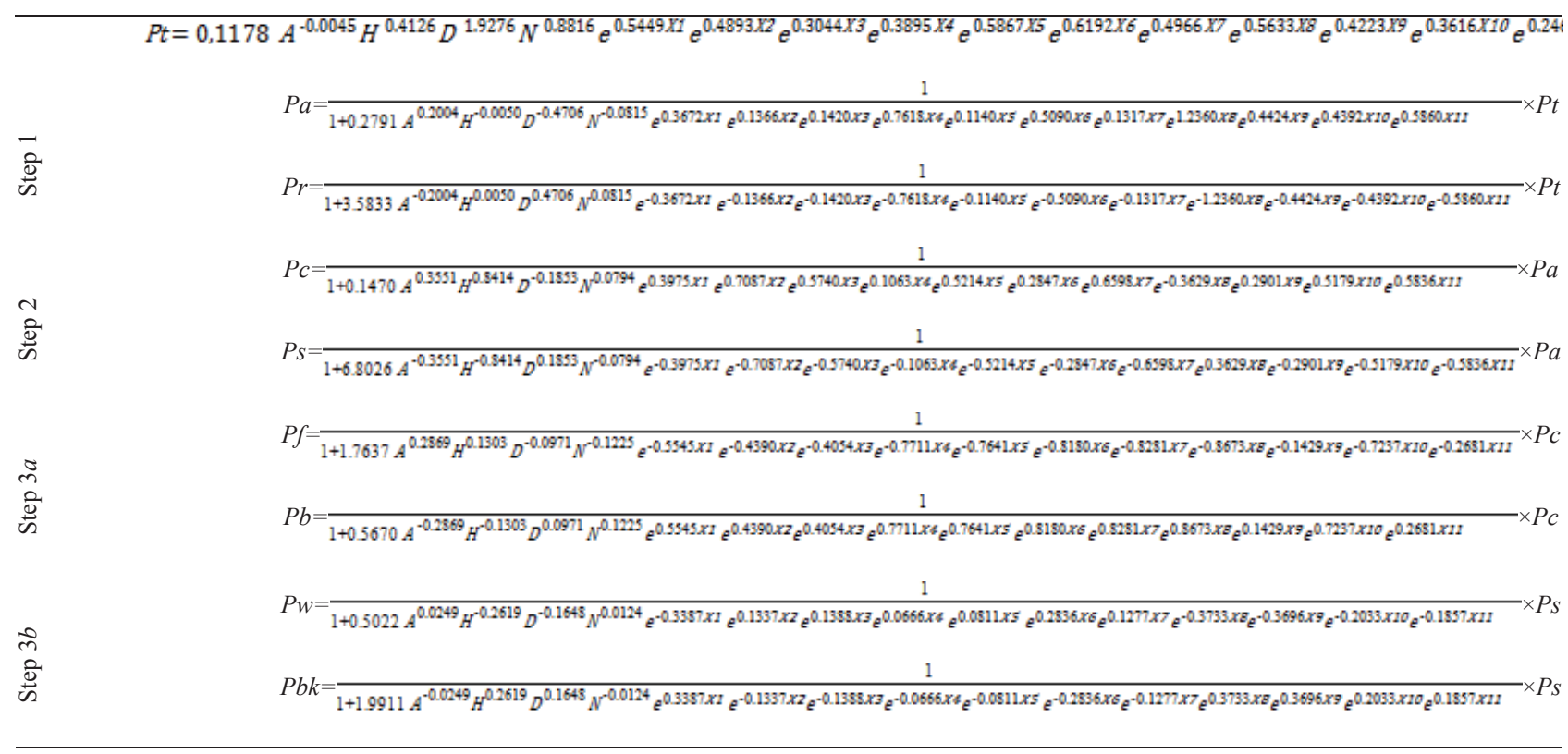

Table 5. The characteristics of "methodized" independent allometric equations for larch stands

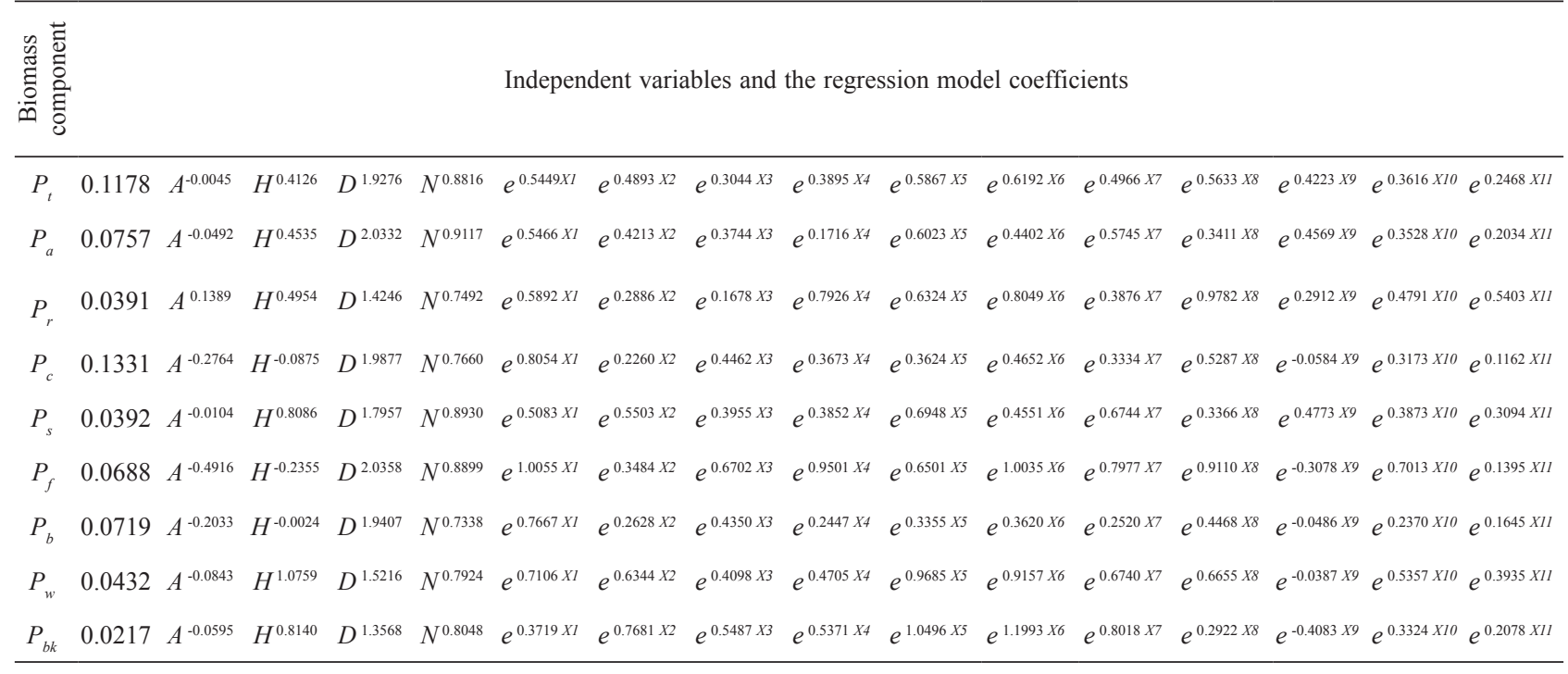



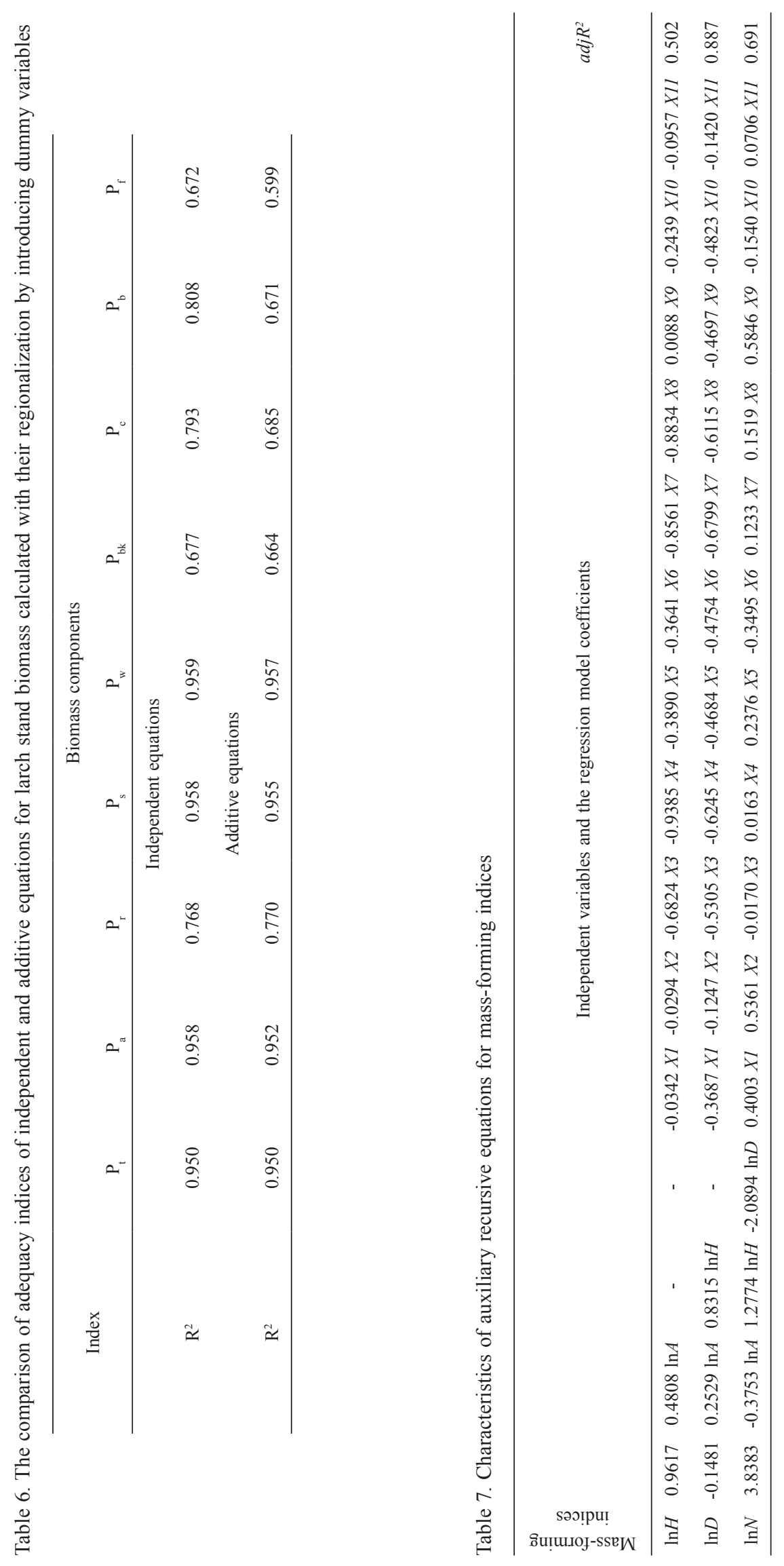

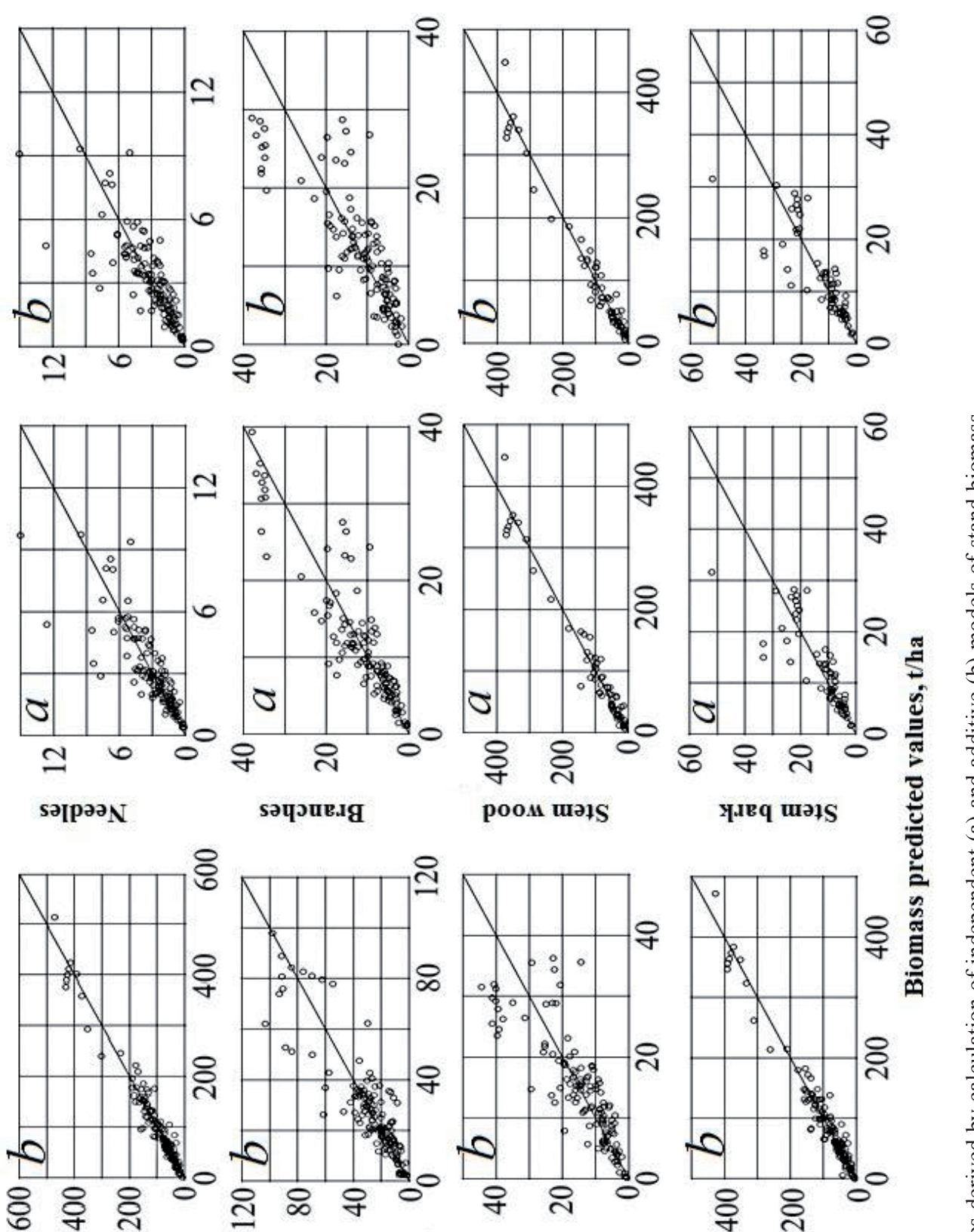
The ratio of actual values and derived ones by tabulating independent and additive stand biomass models (Fig. 3) shows the degree of correlativeness of the actual and calculated values and, in many cases, the absence of visible differences in the structure of residual variances obtained on two named models. More or less the value of $\mathrm{R}^{2}$ of one or the other model is determined by the random position of actual values of maximum stand biomass in confidence range and uneven dispersion, namely accidental because of their small number and the greatest contribution to the residual variance (see Fig. 3).

The additive model built (Table 4) includes four numeric independent variables. When its tabulating, there is a problem, which is that we can know and give the value of stand age only of four variables, and the remaining three variables can be entered into the table in the form of calculated values obtained by the system of auxiliary recursive equations (Usoltsev et al., 2017b). Such equations are approximated using the original data and are shown in the Table 7.

The results of sequential tabulations of the equations of the Table 7 and 4 give the unacceptably voluminous table, the size of which exceeds the format of journal article. Therefore, a comparative analysis of the biomass structure of larch stands of different ecoregions we limit by the stand age of 100 years (Table 8). According to the table. 8 , the greatest values of biomass (210-450 t/ha) correspond to the regions adjacent to the Atlantic and Pacific coasts, as well as to the regions, located at the southern limit of larch growing area and the lowest - to northern taiga regions of Siberia, where larch grows on permafrost. The biomass indices of different ecoregions differed not only in absolute value but also in biomass ratios of different components; for example, the proportion of needles in the aboveground biomass is maximum (5.0-7.3\%) in the northern taiga of Central Siberia and the Far East on permafrost and is minimum (1.4-1.9\%) in larch forests of upper productivity having biomass values $210-450 \mathrm{t} / \mathrm{ha}$.

\section{Conclusion}

When using the unique in terms of the volumes of database on the level of a stand of the genus Larix Mill., the trans-Eurasian additive allometric models of biomass for Eurasian larch forests are developed for the first time, and thereby the combined problem of model additivity and generality is solved. The additive model of forest biomass of Larix is harmonized in two levels, one of which provides the principle of additivity of biomass components, and the second one is associated with the introduction of dummy independent variables localizing model for ecoregions of Eurasia. The proposed model and corresponding tables for estimating stand biomass makes them possible to calculate larch stand biomass on Eurasian forests when using measuring taxation.

Table 8. Fragment of additive transcontinental table of larch stand biomass for the age of 100 years, localized on the ecoregions of Eurasia

\begin{tabular}{|c|c|c|c|c|c|c|c|c|c|c|c|c|c|}
\hline \multirow{2}{*}{ Region } & \multirow{2}{*}{ Species } & \multirow{2}{*}{$H, \mathrm{~m}$} & \multirow{2}{*}{$D, \mathrm{~cm}$} & \multirow{2}{*}{$\begin{array}{c}N, 1000 / \\
\text { ha }\end{array}$} & \multicolumn{9}{|c|}{ Stand biomass, $\mathrm{t} / \mathrm{ha}$} \\
\hline & & & & & $P t$ & $\mathrm{~Pa}$ & $P c$ & $P f$ & $P b$ & $P r$ & Ps & $P w$ & $\mathrm{Pbk}$ \\
\hline WME & L. decidua & 25.7 & 42.0 & 0.3 & 181.0 & 159.8 & 25.7 & 2.8 & 23.0 & 21.2 & 134.1 & 118.9 & 15.2 \\
\hline ER & L. sukaczewii & 24.8 & 28.2 & 0.9 & 407.4 & 336.7 & 34.0 & 6.5 & 27.5 & 70.7 & 302.7 & 275.3 & 27.4 \\
\hline Tst & L. sukaczewii & 24.9 & 36.2 & 0.6 & 447.0 & 387.7 & 31.5 & 5.4 & 26.1 & 59.3 & 356.2 & 309.1 & 47.1 \\
\hline WSn & L. sibirica & 13.0 & 14.0 & 1.1 & 77.0 & 62.6 & 7.7 & 1.3 & 6.4 & 14.4 & 54.9 & 45.2 & 9.7 \\
\hline MSn & L. gmelinii & 10.1 & 10.3 & 1.5 & 56.7 & 38.3 & 7.8 & 1.9 & 5.9 & 18.4 & 30.5 & 24.9 & 5.6 \\
\hline MSs & L. sibirica & 17.4 & 19.0 & 1.1 & 206.1 & 172.7 & 18.8 & 4.3 & 14.5 & 33.4 & 153.9 & 130.7 & 23.3 \\
\hline $\mathrm{TB}$ & L. gmelinii & 17.9 & 19.3 & 0.6 & 132.0 & 101.6 & 14.0 & 3.2 & 10.8 & 30.4 & 87.7 & 72.2 & 15.5 \\
\hline ESn & L. cajanderi & 10.9 & 10.4 & 1.8 & 78.8 & 63.1 & 7.5 & 1.9 & 5.6 & 15.8 & 55.6 & 45.0 & 10.5 \\
\hline FEn & L. cajanderi & 10.6 & 10.9 & 1.6 & 83.2 & 47.7 & 13.4 & 3.5 & 9.9 & 35.5 & 34.3 & 30.0 & 4.3 \\
\hline FEs & L. olgensis & 25.9 & 26.4 & 1.2 & 450.5 & 367.4 & 38.1 & 5.3 & 32.8 & 83.1 & 329.3 & 300.2 & 29.1 \\
\hline $\mathrm{Ch}$ & L. gmelinii & 20.1 & 21.2 & 0.7 & 147.0 & 116.4 & 12.0 & 2.6 & 9.4 & 30.6 & 104.4 & 92.7 & 11.7 \\
\hline Jap & L. leptolepis & 23.3 & 33.6 & 0.4 & 208.8 & 166.2 & 16.2 & 2.3 & 13.9 & 42.6 & 150.0 & 134.7 & 15.3 \\
\hline
\end{tabular}




\section{Acknowledgments}

We thank the anonymous referees for their useful suggestions. This paper is fulfilled according to the programs of current scientific research of the Ural Forest Engineering University and Botanical Garden of the Ural Branch of Russian Academy of Sciences.

\section{References}

Baskerville G.L., 1972, Use of Logarithmic Regression in the Estimation of Plant Biomass. Canadian Journal of Forest Research 2(1): 49-53.

Bi H., Long Y., Turner J., Lei Y., Snowdon P., Li Y., Harper R., Zerihun A. \& Ximenes F., 2010, Additive prediction of aboveground biomass for Pinus radiata (D. Don) plantations. Forest Ecology and Management 259: 2301-2314.

Bi H., Murphy S., Volkova L., Weston Ch., Fairman T., Li Y., Law R., Norris J., Lei X. \& Caccamo G., 2015, Additive biomass equations based on complete weighing of sample trees for open eucalypt forest species in south-eastern Australia. Forest Ecology and Management 349: 106-121.

Bi H., Turner J. \& Lambert M.J., 2004, Additive biomass equations for native eucalypt forest trees of temperate Australia. Trees 18: 467-479.

Bobrov E.G., 1978, Forest-forming conifers of the USSR. Nauka Publishing, Leningrad (in Russian).

Carvalho J.P. \& Parresol B.R., 2003, Additivity in tree biomass components of Pyrenean oak (Quercus pyrenaica Willd.). Forest Ecology and Management 179: 269-276.

Case B.S. \& Hall R.J., 2008, Assessing prediction errors of generalized tree biomass and volume equations for the boreal forest region of west-central Canada. Canadian Journal of Forest Research 38: 878-889.

Chave J., Andalo C., Brown S., Cairns M.A., Chambers J.Q., Eamus D., Folster H., Fromard F., Higuchi N., Kira T., Lescure J.P., Nelson B.W., Ogawa H., Puig H., Riera B. \& Yamakura T., 2005, Tree allometry and improved estimation of carbon stocks and balance in tropical forests. Oecologia 145: 87-99.

Chave J., Réjou-Méchain M., Búrque, A., Chidumayo E., Colgan M.S., Delitti W.B.C., Duque A., Eid T., Fearnside P.M., Goodman R.C., Henry M., Martínez-Yrízar A., Mugasha W.A., Muller-Landau H.C., Mencuccini M., Nelson B.W., Ngomanda A., Nogueira E.M., Ortiz-Malavassi E., Pélissier R., Ploton P., Ryan C.M., Saldarriaga J.G. \& Vieilledent G., 2014, Improved allometric models to estimate the aboveground biomass of tropical trees. Global Change Biology 20: 3177-3190.
Crow T.R., 1978, Common regressions to estimate tree biomass in tropical stands. Forest Science 24(1): 110-114.

Crow T.R., 1983, Comparing biomass regressions by site and stand age for red maple. Canadian Journal of Forest Research 13: 283-288.

Crowther T.W., Glick H.B., Covey K.R., Bettigole C., Maynard D.S., Thomas S.M., Smith J.R., Hintler G., Duguid M.C., Amatulli G., Tuanmu M.-N., Jetz W., Salas C., Stam C., Piotto D., Tavani R., Green S., Bruce G., Williams S.J., Wiser S.K., Huber M.O., Hengeveld G.M., Nabuurs G.-J., Tikhonova E., Borchardt P., Li C.-F., Powrie L.W., Fischer M., Hemp A., Homeier J., Cho P., Vibrans A.C., Umunay P.M., Piao S.L., Rowe C.W., Ashton M.S., Crane P.R. \& Bradford M.A., 2015, Mapping tree density at a global scale. Nature 525: 201-205.

Cunia T. \& Briggs R.D., 1984, Forcing additivity of biomass tables: some empirical results. Canadian Journal of Forest Research 14: 376-384.

De-Miguel S., Mehtätalo L. \& Durkaya A., 2014, Developing generalized, calibratable, mixed-effects metamodels for large-scale biomass prediction. Canadian Journal of Forest Research 44: 648-656.

Dieguez-Aranda U., Burkhart H.E. \& Amateis R.L., 2006, Dynamic site model for loblolly pine (Pinus taeda L.) plantations in the United States. Forest Science 52(3): 262-272.

Dong L., Zhang L. \& Li F., 2015a, Developing additive systems of biomass equations for nine hardwood species in Northeast China. Trees 29(4): 1149-1163. (https://doi.org/10.1007/s00468-015-1196-1).

Dong L., Zhang L. \& Li F., 2015b, A three-step proportional weighting system of nonlinear biomass equations. Forest Science 61(1): 35-45.

Dong L., Zhang L. \& Li F., 2016, Developing two additive biomass equations for three coniferous plantation species in Northeast China. Forests 7(7): 136.

Fehrmann L., Lehtonen A., Kleinn C. \& Tomppo R., 2008, Comparison of linear and mixed-effect regression models and a k-nearest neighbor approach for estimation of single tree biomass. Canadian Journal of Forest Research 38: 1-9.

Fu L.Y., Zeng W.S., Tang S.Z., Sharma R.P. \& Li H.K., 2012, Using linear mixed model and dummy variable model approaches to construct compatible single-tree biomass equations at different scales - A case study for Masson pine in Southern China. Journal of Forest Science 58(3): 101-115.

Fu L., Sharma R.P., Hao K. \& Tang S., 2017, A generalized interregional nonlinear mixed-effects crown width model for Prince Rupprecht larch in northern China. Forest Ecology and Management 389: 364-373.

Fu L., Sun H., Sharma R.P., Lei Y., Zhang H. \& Tang S., 2013, Nonlinear mixed-effects crown width models for 
individual trees of Chinese fir (Cunninghamia lanceolata) in south-central China. Forest Ecology and Management 302: 210-220.

Gill R.A. \& Jackson R.B., 2000, Global patterns of root turnover for terrestrial ecosystems. New Phytologist 147: $13-31$.

Grigal D.F. \& Kernik L.K., 1984, Generality of black spruce biomass estimation equations. Canadian Journal of Forest Research 14: 468-470.

Jacobs M.W. \& Cunia T., 1980, Use of dummy variables to harmonize tree biomass tables. Canadian Journal of Forest Research 10(4): 483-490.

Jucker T., Caspersen J., Chave J., Antin C., Barbier N., Bongers F., Dalponte M., van Ewijk K.Y., Forrester D.I., Heani M., Higgins S.I., Holdaway R.J., Iida Y., Lorimer C., Marshall P.M., Momo S., Moncrieff G.R., Ploton P., Poorter L., Rahman K.A., Schlund M., Sonké B., Sterck F.J., Trugman A.T., Usoltsev V.A., Vanderwel M.C., Waldner P., Wedeux B., Wirth C., Wöll H., Woods M., Xiang W., Zimmermann N. \& Coomes D.A., 2017, Allometric equations for integrating remote sensing imagery into forest monitoring programmes. Global Change Biology 23: 177-190.

Lang P.M., 2008, Linear mixed model of aerial photo crown width and ground diameter. Scientia Silvae Sinicae 44: 41-44.

Li L.X., Hao Y.H. \& Zhang Y., 2006, The application of dummy variable in statistic analysis. The Journal of Mathematical Medicine 19: 51-52.

Li C.M. \& Zhang H.R., 2010, Modeling dominant height for Chinese fir plantation using a nonlinear mixed-effects modeling approach. Scientia Silvae Sinicae 46: 89-95.

Liang J., Crowther T.W., Picard N., Wiser S., Zhou M., Alberti G., Schulze E.-D., McGuire A.D., Bozzato F., Pretzsch H., de-Miguel S., Paquette A., Hérault B., Scherer-Lorenzen M., Barrett C.B., Glick H.B., Hengeveld G.M., Nabuurs G.-J., Pfautsch S., Viana H., Vibrans A.C., Ammer C., Schall P., Verbyla D., Tchebakova N.M., Fischer M., Watson J.V., Chen H.Y.H., Lei X., Schelhaas M.-J., Lu H., Gianelle D., Parfenova E.I., Salas C., Lee E., Lee B., Kim H. S., Bruelheide H., Coomes D.A., Piotto D., Sunderland T., Schmid B., Gourlet-Fleury S., Sonké B., Tavani R., Zhu J., Brandl S., Vayreda J., Kitahara F., Searle E.B., Neldner V.J., Ngugi M.R., Baraloto C., Frizzera L., Bałazy R., Oleksyn J., Zawiła-Niedźwiecki T., Bouriaud O., Bussotti F., Finér L., Jaroszewicz B., Jucker T., Valladares F., Jagodzinski A.M., Peri P.L., Gonmadje C., Marthy W., O’Brien T., Martin E.H., Marshall A.R., Rovero F., Bitariho R., Niklaus P.A., Alvarez-Loayza P., Chamuya N., Valencia R., Mortier F., Wortel V., Engone-Obiang N.L., Ferreira L.V., Odeke D.E., Vasquez R.M., Lewis S.L. \& Reich P.B., 2016, Positive biodiversity - pro- ductivity relationship predominant in global forests. Science 354(6309): 196-208.

Nord-Larsen T., 2006, Developing dynamic site index curves for European beech (Fagus sylvatica L.) in Denmark. Forest Science 52(2): 173-181.

Ogawa H., Yoda K., Ogino K. \& Kira T., 1965, Comparative ecological studies on three main types of forest vegetation in Thailand. 2. Plant biomass. Nature and Life in Southeast Asia 4: 49-80.

Parresol B.R., 2001, Additivity of nonlinear biomass equations. Canadian Journal of Forest Research 31(5): 865878.

Pastor J., Aber J.D. \& Melillo J.M., 1984, Biomass prediction using generalized allometric regressions for some Northeast tree species. Forest Ecology and Management 7: 265-274.

Poorter H., Jagodzinski A.M., Ruiz-Peinado R., Kuyah S., Luo Y., Oleksyn J., Usoltsev V.A., Buckley T.N., Reich P.B. \& Sack L., 2015, How does biomass allocation change with size and differ among species? An analysis for 1200 plant species from five continents. New Phytologist 208(3): 736-749.

Reed D.D. \& Green E.J., 1985, A method of forcing additivity of biomass tables when using nonlinear models. Canadian Journal of Forest Research 15: 1184-1187.

Rutishauser E., Noor'an F., Laumonier Y., Halperin J., Rufi'ie, Hergoualch K. \& Verchot L., 2013, Generic allometric models including height best estimate forest biomass and carbon stocks in Indonesia. Forest Ecology and Management 307: 219-225.

Sanquetta C.R., Behling A., Corte1 A.P.D., Netto S.P., Schikowski A.B. \& do Amaral M.K., 2015, Simultaneous estimation as alternative to independent modeling of tree biomass. Annals of Forest Science 72: 10991112.

Schenk H.J. \& Jackson R.B., 2002, The global biogeography of roots. Ecological Monographs 72(3): 311-328.

Schenk H.J. \& Jackson R.B., 2003, A global database of ecosystem root profiles (ERP). California State University, Fullerton.

Schmitt M.D.C. \& Grigal D.F., 1981, Generalized biomass estimation equations for Betula papyrifera Marsh. Canadian Journal of Forest Research 11: 837-840.

Sokolov S.Y., Svyazeva O.A. \& Kubli V.A., 1977, Areas of trees and shrubs of the USSR. Vol. 1. Nauka Publishing, Leningrad (in Russian).

Stas S.M., Rutishauser E., Chave J., Anten N.P.R. \& Laumonier Y., 2017, Estimating the aboveground biomass in an old secondary forest on limestone in the Moluccas, Indonesia: Comparing locally developed versus existing allometric models. Forest Ecology and Management 389: 27-34.

Tang S., Zhang H. \& Xu H., 2000, Study on establish and estimate method of compatible biomass model. Scien- 
tia Silvae Sinica 36: 19-27 (in Chinese with English abstract).

Tang S.Z., Lang K.J. \& Li H.K., 2008, Statistics and computation of biomathematical models (ForStat Course). Science Press, Beijing.

Tritton L.M. \& Hornbeck J.W., 1981, Biomass estimation for northeastern forests. Bulletin of the Ecological Society of America 62: 106-107.

Usoltsev V.A., 2010, Eurasian forest biomass and primary production data. Ural Branch of Russian Academy of Sciences, Yekaterinburg. (http://elar.usfeu.ru/handle/123456789/2606).

Usoltsev V.A., 2013, Forest biomass and primary production database for Eurasia. CD-version. The second edition, enlarged and re-harmonized. Ural State Forest Engineering University, Yekaterinburg. (http://elar.usfeu. ru/handle/123456789/3059).

Usoltsev V.A., Koltunova A.I., Kajimoto T., Osawa A. \& Koike T., 2002, Geographical gradients of annual biomass production from larch forests in Northern Eurasia. Eurasian Journal of Forest Research 5: 55-62.

Usoltsev V.A., Voronov M.P., Kolchin K.V., Malenko A.A. \& Kokh E.V., 2017a. Transcontinental additive model and weight table for estimating spruce-fir forests biomass on the area of Eurasia. Bulletin of Altai State Agricultural University 9(155): 91-100. (http://www.asau. ru/vestnik/2017/9/091-100.pdf).

Usoltsev V.A., Voronov M.P., Shobairi S.O.R., Dar J.A., Kolchin K.V., Chasovskikh V.P., Markovskaya E.V., 2017b. Comparative analysis of ordinary and additive models of component composition of tree and forest biomass (on the example of Picea and Abies spp.). Èko-potencial 3(19): 9-31. (http://elar.usfeu.ru/bitstream/123456789/6638/1/eko_17-3_01.pdf).

Vieilledent G., Vaudry R., Andriamanohisoa S.F.D., Rakotonarivo O.S., Randrianasolo Z.H., Razafindrabe H.N., Bidaud Rakotoarivony C., Ebeling J. \& Rasamoelina M., 2012, A universal approach to estimate biomass and carbon stock in tropical forests using generic allometric models. Ecological Applications 22(2): 572-583.

Wang M., Borders B.E. \& Zhao D.H., 2007, Parameter estimation of base-age invariant site index models: which data structure to use?. Forest Science 53(5): 541-551.

Wang M., Borders B.E. \& Zhao D., 2008, An empirical comparison of two subject-specific approaches to dominant heights modeling: The dummy variable method and the mixed model method. Forest Ecology and Management 255: 2659-2669.

Zeng W.S., 2015, Using nonlinear mixed model and dummy variable model approaches to construct origin-based single tree biomass equations. Trees 29(1): 275-283.

Zeng W.S., Tang S.Z., Xia Z.S., Zhu S. \& Luo H.Z., 2011, Using linear mixed model and dummy variable model approaches to construct generalized single-tree biomass equations in Guizhou. Forest Research 24(3): 285-291.

Zianis D. \& Mencuccini M., 2003, Aboveground biomass relationships for beech (Fagus moesiaca Cz.) trees in Vermio Mountain, Northern Greece, and generalized equations for Fagus sp. Annals of Forest Science 60: 439-448. 